\title{
Entrepreneurial Education in the Context of the Imperative Development of Sustainable Business
}

\author{
By Carmen Valentina Rădulescuํ, Sorin Burlacu², Dumitru Alexandru Bodislav², \\ Florina Bran ${ }^{4}$
}

\begin{abstract}
Entrepreneurial education is one of the fastest growing areas in the world today, with a growing interest in academia, which allows the possibility of linking current labor market needs to academic theory. The purpose of this article is to make a positive contribution to the formation of future entrepreneurship programs, by analyzing existing curricula to identify potential educational gaps, as well as to identify the skills needed by students in the context of sustainable business development. This will allow entrepreneurial trainers to exchange ideas that facilitate collective learning and help inform researchers about the future directions of education. This article will focus on the analysis of existing entrepreneurship education at the international level, as well as on the development of suggestions on how entrepreneurship education can progress further, as a way of shaping the future development of the economy.
\end{abstract}

Keywords: entrepreneurial education, sustainable business, sustainable development

\section{Introduction}

Entrepreneurial education has emerged in every educational context, primarily for the growth of an entrepreneurial enterprise, to create a new project, and for a mentally charged enterprise for entrepreneurship through education and learning (Kuratko, 2005).

It is necessary to formulate an education system that allows for rapid adaptation, to build the capacity of students to recognize an opportunity and to create networks, to partnerships (for a complex approach to problems and to legislate them) and to ensure that they can ensure that they are able to align the need for sustainable growth and business.

We must also be careful that they neglect aspects of community needs and social entrepreneurship, so they must remain in the current context of unmistakable care (pollution, climate change, foam, etc.) in order to create sustainable care have a positive impact on societies as a whole.

The entrepreneurial approach is also adopted through the work of non-governmental organizations (NGOs), which, although not profit-oriented, have an equally effective mode of action, and in relation to sustainable development are very relevant, as they seek to create value, but not economic, expressed by profit, but social or ecological, expressed by contributions to solving social or environmental problems. In fact, NGOs are playing 
an increasingly important role in the economy and society. At European level, more than 5 million associations were inventoried, with more than 100 million members managing funds totaling 6.4 billion euros (Ionescu, 2002)

Depending on the annual budget of the projects carried out, the most important NGOs in Europe are Greenpeace (120 million euros), Friends of the Earth (75 million euros), Amnesty International (50 million euros), World Wild Fund for Nature (20 million euros). million), Oxfam (10 million) and others. In addition, NGOs establish various forms of collaboration with the business environment, facilitating fundraising to fund projects that bring social and / or environmental benefits (Bloom, 2008).

Globalization is a complex process that has continued to intensify in recent decades. Although similar forms of economic, social and political interactions have been identified and described for different historical stages, the contemporary process is distinguished by the importance of the economic dimension facilitated by modern information and communication technologies. In this context, the influence of multinational companies has increased significantly. Multinational companies participate with more than $60 \%$ in world trade, dominating the production, distribution and sale of many products so that they have enough power to guide social change globally and nationally (Brat et al., 2013)

Many environmental issues considered important - the threat of climate change, depletion of mineral resources, deforestation, etc. - have worsened in recent decades. To these are added the perpetuation and even the deepening of global development gaps and poverty. These trends have manifested themselves in the context of the increasingly coherent application of prevention and control measures initiated at the governmental level, so that it has become clear the need to accelerate change, possible through the direct involvement of the business environment (Bran et al., 2011).

The business environment is the sensory exponent of the economy, at which macroeconomic and global trends are constantly scrutinized very carefully to gain a temporary competitive advantage. The orientation towards sustainable development, promoted more and more intensely both at the declarative level, and especially through regulations, standards and instruments based on the market mechanism (environmental taxes, negotiable pollution permits, etc.) did not go unnoticed, so that more and more companies have adapted their mission and values to the new requirements (Bran et al, 2013).

The business environment plays a key role in progress towards sustainable development because private sector activity in competitive conditions specific to the market economy is the main cause of the social and environmental problems that generate critical situations. Businesses create added value by using the natural resources they transform, a process in which they also generate pollution. Therefore, changing the way they add value will also reduce pollution, thus contributing to the achievement of sustainable development goals.

In order to meet the challenge of sustainable development, the business environment will need to consider changes in relation to the following issues (WBCSD, 2010):

- Accepting the constraints and opportunities of a world with limited natural resources that will soon be populated by 9 billion people;

- Redefining success and progress at national, company and individual level; 
- Increasing bioproductivity;

- Creating solutions with low ecological impact that maintain the quality of life in developed countries that have an unacceptably large ecological footprint;

- Improving human development in developing countries without increasing the ecological footprint beyond acceptable limits.

The business environment must become part of the solution to achieving the goals of sustainable development. It must be accepted that no government program is comparable to the business environment in terms of job creation, well-being and innovation that improve living standards and social conditions (Porter \& Kramer, 2006). Moreover, the implementation of government policies aims to create incentives to change the economic environment, so that business decisions have consequences consistent with the interests of society. However, the effectiveness of these measures has proved its limitations in that the pace of change does not meet the requirements of sustainable development, so a qualitative leap is needed to transform the way business creates value. This means that business management must recognize its responsibility for sustainable development and be actively involved in identifying opportunities for change to ensure a long-term perspective.

\section{Entrepreneurial Education}

Entrepreneurial education is often approached from three perspectives (Johnson, 1988, Heinonen and Hytti, 2010, O'Connor, 2013).

1. Learning "about" entrepreneurship means a theoretical approach loaded with content and which aims to provide a general understanding of the phenomenon. It is the most common approach in higher education institutions (Mwasalwiba, 2010).

2. Teaching entrepreneurship "for" means an occupational-oriented approach aimed at providing emerging entrepreneurs with the necessary knowledge and skills.

3. "Through" learning means a process-based and often experimental approach in which students go through a real entrepreneurial learning process (Kyrö, 2005).

The latter approach is often based on the broader definition of entrepreneurship and can be integrated into other subjects in general education, connecting entrepreneurial characteristics, processes and experiences to the core subject. While the "about" and "for" approaches are relevant primarily to pupils at secondary and higher education levels, the integrated approach to teaching "through" entrepreneurship may be relevant for all pupils and students at all levels of education. education (see for example Smith et al., 2006, Handscombe et al., 2008, Lackéus, 2015) ${ }^{1}$.

\section{Why is Entrepreneurial Education Needed?}

Entrepreneurial education cultivates innovative talents, which are an important driving force for the future development of sustainable business. Currently, innovationbased development strategies demand new demands for entrepreneurship education.

\footnotetext{
${ }^{1}$ Martin Lackéus, (2015), Entrepreneurship in Education, What, Why, When, How, OECD and European Commission
} 
However, current research and discussions in this area focus on teacher training in the entrepreneurship education ecosystem (Ruskovaara and Pihkala, 2015) on the hypothesis that entrepreneurship education can influence students' intention to become entrepreneurs (Martin et al., 2013; Pittaway and Cope, 2016) and on curriculum development (Falck et al., 2016).

Based on the theory of social cognition, the individual and environmental characteristics of students greatly influence the achievement of entrepreneurship education. In-depth studies of the mechanism of entrepreneurship education can further enhance entrepreneurship education research and can lead to innovation and development (Baum et al., 2001; Morris et al., 2013).

Innovation is considered the internal engine of a market economy based on sustainable business. Innovation is the result of entrepreneurial thinking; thus, the development of new products or entry into new markets and is the result of entrepreneurship (Miller, 1983; Covin and Slevin, 1989). Entrepreneurial education, for entrepreneurs, is an important way to acquire knowledge to improve innovative capacity and innovative personality, as well as to build multi-level learning channels by integrating various knowledge and value systems.

From acquiring knowledge to improving skills, entrepreneurship education includes the general development of skills and the improvement of professional capacity. Entrepreneurial competence refers in particular to the ability to identify opportunities and develop the necessary resources and capital and is important for success (Arthurs and Busenitz, 2006; Kettunen et al., 2013), in addition to technical, financial and legal knowledge. (Kuratko, 2005). Given that entrepreneurial capacity is diversified, some authors (Bacigalupo et al., 2016) build an entrepreneurial competence framework that includes identifying opportunities, entrepreneurial skills that represent "resources", areas of action and 15 lists of competencies.

Gianesini et al. (2018) compared the models and classifications of entrepreneurial skills, arguing that entrepreneurial skills consist of personality traits, entrepreneurial knowledge and skills. Entrepreneurship research is increasingly concerned with knowledge and experience relevant to improving skills and developing potential resources for improving innovation ${ }^{2}$.

Entrepreneurship programs run by business schools equate entrepreneurship with creating and taking new risks and educate "about" entrepreneurship, rather than entrepreneurship education (Kirby, 2004).

The set of skills needed to become an entrepreneur includes; persuasion skills, creativity, critical thinking, leadership skills, negotiation skills, problem solving skills, social networking and time management (Rae, 2007).

To activate creativity and innovation, it is necessary to think correctly addresses uncertainties, open-ended questions, making decisions with incomplete information, lateral thinking, intuitive thinking (Lewis, 1987).

Currently, entrepreneurship education programs use a variety of teaching methods, including lectures, guests, case studies, and role models (Solomon, 2007; Wilson et al.,

2 Xingiian Wei, Xiaolang Liu and Jian Sha, (2019), How Does the Entrepreneurship Education Influence the Students' Innovation? Testing on the Multiple Mediation Model, 
2007).

When designing the education program for entrepreneurs, the following aspects must be taken into account:

- the specific requirements of the students must be understood;

- teaching should be more specific to students' requirements;

- teaching methods should be used to provide new information, such as lectures, readings, text and seminar analysis active case studies, group discussions, brainstorming, etc.

These methods used to develop skills; solving problems in the real situation should be done by partnering with small companies to provide advice to provide practical experience.
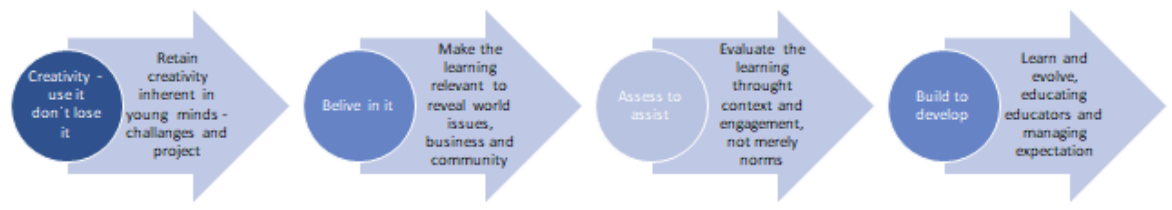

\section{More problems and more answers = divergent thinking - one size doesn`t filt all}

Fig. no. 1. Model of entrepreneurial education

Source: Adaptation after Penaluna and Penaluna, 2009

The entrepreneurial education model identifies four aspects of the individual in relation to the socio-economic environment: creativity, faith, assets for assistance, construction and development. Creativity is considered paramount only when it is not allowed to deconstruct some fundamental aspects. Usually, young minds come up with their creative innocence without compromising grounded procedures. Challenges are often welcomed in entrepreneurship education as a development of projects.

Belief in success can be an important part of the creative process if learning is real and relevant to aspects of life, business or the community. Assistance tools are often used for context assessment and real commitments and not just formal or normative. The construction and development of entrepreneurial education is achieved through educators and learners, the latter putting all their expectations on the shoulders of the first who must not disappoint and properly manage learning situations, without creating unrealistic expectations.
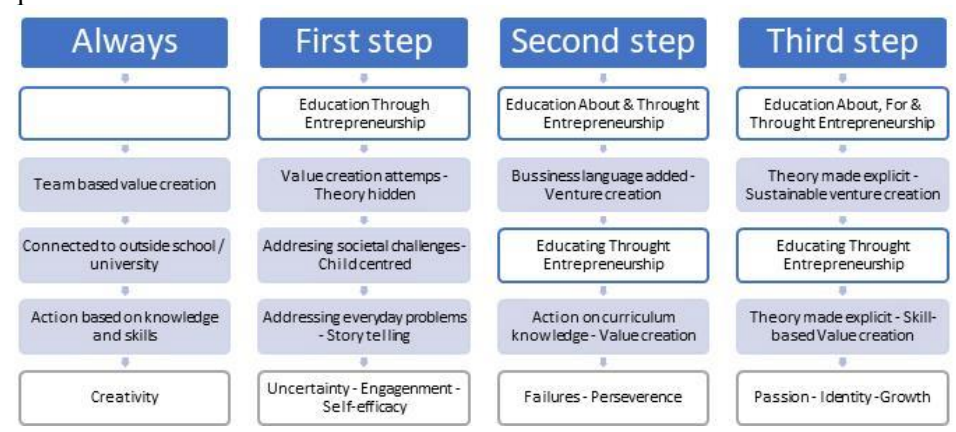

Fig. no. 2. A unified progression model for entrepreneurial education

Source: Adaptation after Lackeus, M. (2015). 


\section{Conclusions}

The product, respectively the entrepreneurial training program, at business schools, must be evaluated based on behavioral and competence results, product development, prototypes, etc. (Hynes, 1996). It is very important to take into account first of all the business environment that operates in that country and not, last but not least, the requirements that exist in the context of globalization.

It was also found that there are gender differences between the motivating factors that determine participation in the entrepreneurship program. Therefore, it is necessary to customize education programs to meet the needs of female and male students.

Entrepreneurship programs should be designed to inform students about real-world conditions and to present ways in which they can overcome their complexes and take risks, in order to participate in creating a sustainable economy (Petridou et al., 2009). ${ }^{3}$

\section{References}

Penaluna, A., and Penaluna, K., (2009), Entrepreneurial in Education in Practice, OECD and European Commission

Arthurs, J. D., and Busenitz, L. W. (2006). Dynamic capabilities and venture performance: the effects of venture capitalists. J. Bus. Ventur. 21, 195-215. doi: 10.1016/j.jbusvent.2005.04.004

Bacigalupo, M., Kampylis, P., Punie, Y., and Van den Brande, G. (2016). EntreComp: the entrepreneurship competence framework. (Luxembourg: Publication Office of the European Union). doi: $10.2791 / 593884$

Bloom, R. (2008). ENGOF European NGO Futures. A study of Europe's leading NGOs and their contribution to policymaking in Brussels. SIGWatch, Freiburg.

Bran, F., Ioan, I., Rădulescu, C.V. (2013). Verde devine culoarea afacerii de succes, Calitatea - acces la succes, 14 (134): 113-116.

Bran, F., Manea, G., Ioan, I. Rădulescu, C.V. (2013). Globalizarea. Manifestări și reacții, Editura Economică, București, pg.36.

Bran, F., Rădulescu, C.V., Ioan, I., Popa, C. (2011). Sinergii globale în direcția protecției mediului. Editura Universitară, București.

Gianesini, G., Cubico, S., Favretto, G., and Leitão, G. C. C. (2018). "Entrepreneurial competences: comparing and contrasting models and taxonomies" in Entrepreneurship and the industry life cycle. Vol. 6, eds. S. Cubico, G. Favretto, J. Leitão, and U. Cantner (Cham, Switzerland: Springer International Publishing), 13-32. doi: 10.1007/978-3-319-89336-5_2

Handscombe, R. D., Rodriguez-Falcon, E. \& Patterson, E. A. 2008. Embedding enterprise in science and engineering departments. Education+ Training, 50, 615-625.

Hynes, B. (1996). Entrepreneurship education and training \# introducing entrepreneurship into non business disciplines. Journal of European Industrial Training, 20(8), 10-17. doi:10.1108/03090599610128836

Ioan, I., Bran, F., Radulescu, C. V. (2014). Managerial challenges of the green economy. Managerial Challenges of the Contemporary Society. Proceedings, 7(1), 125-130.

Ionescu, A.G. (2002). Organizațiile neguvernamentale în economia mondială, Editura ASE, București.

Johnson, C. 1988. Enterprise education and training. British Journal of Education and Work, 2, 61-65

Kettunen, J., Kairisto-Mertanen, L., and Penttilä, T. (2013). Innovation pedagogy and desired learning outcomes in higher education. On the Horiz. 21, 333-342. doi: 10.1108/OTH-08-2011-0024

Kirby, D. A. 2004. Entrepreneurship education: can business schools meet the challenge? Education + Training, 46, 510-519

${ }^{3}$ Mukta Mani, (2015), Entrepreneurship Education:A Students' Perspective, International Journal of EEntrepreneurship and Innovation, 5(1), 1-14, January-June 2015 
Kuratko, D. F. (2005). The emergence of entrepreneurship education: development, trends, and challenges. Entrep. Theory Pract. 29, 577-598. doi: 10.1111/j.1540-6520.2005.00099.x

Kuratko, D. F. 2005. The emergence of entrepreneurship education: Development, trends, and challenges. Entrepreneurship Theory and Practice, 29, 577-597.

Kyrö, P. 2005. Entrepreneurial learning in a cross-cultural context challenges previous learning paradigms. In: Kyrö, P. \& Carrier, C. (eds.) The Dynamics of Learning Entrepreneurship in a Cross-Cultural University Context. Hämeenlinna: University of Tampere.

Lackeus, M. (2015). Entrepreneurship in Education-What, Why, When, How. Entrepreneurship360 Background Paper, OECD, France.

Lewis, D. (1987). Mind Skills: Giving Your Child a Brighter Future. London: Souvenir Press.

Martin Lackéus, (2015), Entrepreneurship in Education, What, Why, When, How, OECD and European Commission

Mukta Mani, (2015), Entrepreneurship Education: A Students' Perspective, International Journal of EEntrepreneurship and Innovation, 5(1), 1-14, January-June 2015,

Mwasalwiba, E. S. 2010. Entrepreneurship education: a review of its objectives, teaching methods, and impact indicators. Education + Training, 52 20-47.

Petridou, E., Sarri, A., \& Kyrgidou, L. P. (2009). Entrepreneurship education in higher educational institutions: The gender dimension. Gender in Management: An International Journal, 24(4), 286309. doi:10.1108/17542410910961569

Porter, M. E., Kramer, M. R. (2006). Strategy and Society. The Link Between Competitive Advantage and Corporate Social Responsibility. Harvard Business Review, 85(12).

Rae, D. 2007. Entrepreneurship: from opportunity to action, New York, NY, Palgrave Macmillan

Solomon, G. (2007). An examination of entrepreneurship education in the United States. Journal of Small Business and Enterprise Development, 14(2), 168-182. doi:10.1108/14626000710746637

WBCSD (2010). Vision 5050. The new agenda for business.

Wilson, F., Kickul, J. and Marlino, D. (2007), "Gender, entrepreneurial self-efficacy, and entrepreneurial career intentions: implications for entrepreneurship education", Entrepreneurship Theory \& Practice, 387-406.

Xingian Wei, Xiaolang Liu and Jian Sha, (2019), How Does the Entrepreneurship Education Influence the Students' Innovation? Testing on the Multiple Mediation Model, 